\title{
"You have to get to where you are before you can see where you've been": Searching for Black Queer Domesticity at Chez Baldwin ${ }^{1}$
}

\author{
Magdalena J. Zaborowska University of Michigan
}

\begin{abstract}
This essay argues for the importance of James Baldwin's last house, located in St. Paul-de-Vence in the south of France, to his late works written during the productive period of 1971-87: No Name in the Street (1972), If Beale Street Could Talk (1974), The Devil Finds Work (1976), Just Above My Head (1979), The Evidence of Things Not Seen (1985), and the unpublished play The Welcome Table (1987). That period ushered in a new Baldwin, more complex and mature as an author, who became disillusioned while growing older as a black queer American who had no choice but to live abroad to get his work done and to feel safe. Having established his most enduring household at "Chez Baldwin," as the property was known locally, the writer engaged in literary genre experimentation and challenged normative binaries of race, gender, and sexuality with his conceptions of spatially contingent national identity. The late Baldwin created unprecedented models of black queer domesticity and humanism that, having been excluded from U.S. cultural narratives until recently, offer novel ways to reconceptualize what it means to be an American intellectual in the twenty-first-century world.
\end{abstract}

Keywords: Chez Baldwin, St. Paul-de-Vence, France, late Baldwin, social space, black queer domesticity

From his house in St. Paul-de-Vence in the south of France, where the last sixteen years of his life generated such complex works as No Name in the Street (1972), If Beale Street Could Talk (1974), The Devil Finds Work (1976), Just Above My Head

James Baldwin Review, Volume 4, 2018, (c) The Authors. Published by Manchester University Press and The University of Manchester Library 
(1979), The Evidence of Things Not Seen (1985), and the unpublished play The Welcome Table (1987), James Baldwin describes the enmeshing of his domesticity and its material and metaphorical qualities with his authorial craft:

Sitting in the strangest house I have ever known-because I am in the process of moving into it-like a squirrel, I rummage, not without panic, through drawers and boxes, trunks, old suit-cases, books, checking to see if my hoard will carry me through what remains of the winter of my life, and I am stopped by a fragment, scribbled on a piece of paper, in my hand, God knows when...

These words come from an image of the writer's study and typewriter taken shortly after his death by the documentary filmmakers Karen Thorsen and Douglas Dempsey. The image appears in their documentary, James Baldwin: The Price of the Ticket (1989), offering a glimpse of the writer's table facing away from a window flooded with sunshine. A closer look at the sheet of paper in the typewriter reveals these words, whose rich, mysterious texture reminds us that Baldwin dreamt of writing new projects to his dying day.

It is unclear what Baldwin was drafting-perhaps Remember This House, which was to take on the lives and assassinations of "Medgar, Malcolm, and Martin," or No Papers for Mohammed, in which the Algerian gardener from his unpublished

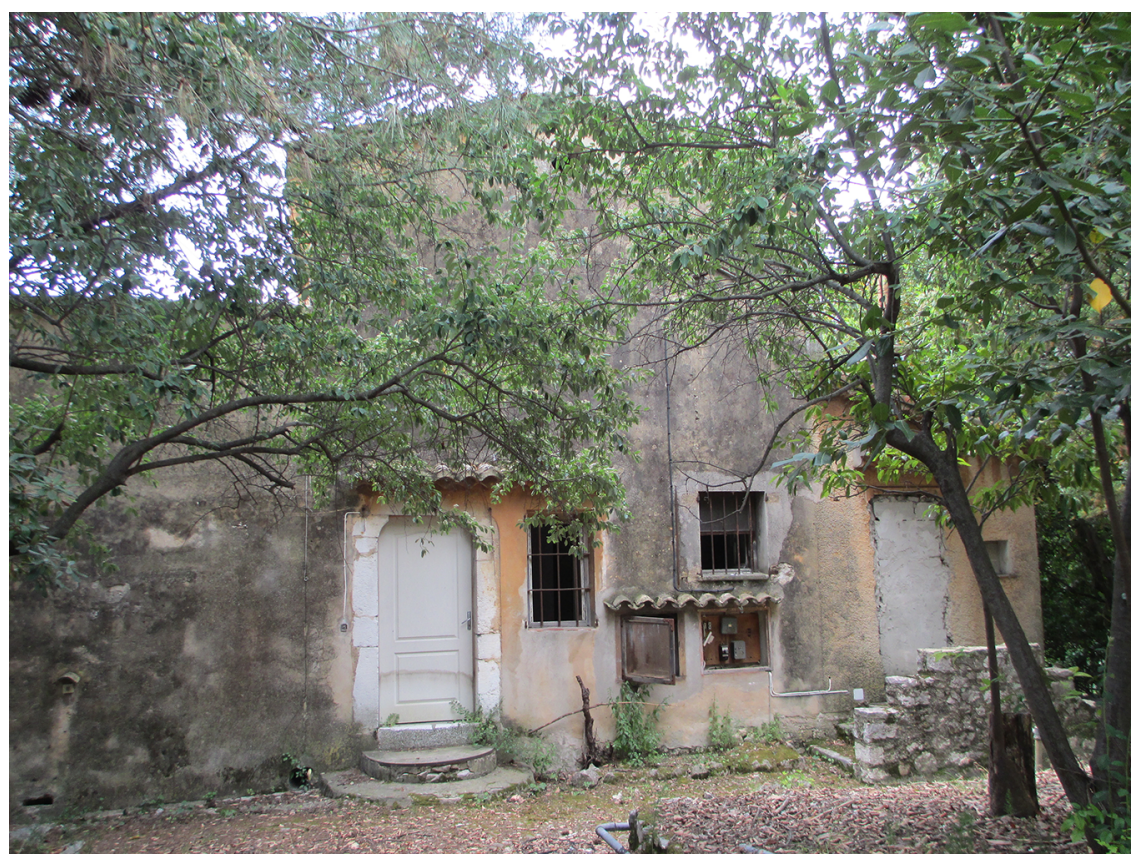

Figure 1 Chez Baldwin front, St. Paul-de-Vence, France. Photo by author, 2014 
last play, The Welcome Table (1987), based on the writer's onetime employee, was to become the central character. ${ }^{2}$ That this mysterious sheet of paper is, indeed, the last one Baldwin touched is apparent when, looking at the still taken from the film footage, one notices a slightly wilted, bright red flower on a tray on the other side of the table and a tall, reddish votive candle next to it. The room becomes a still life, a sanctuary, a space of mourning and absence. The permanence of this still life has been compounded by the fact that the wing of the house where it was once located-with all the vibrant creativity and passion that must have filled it-was permanently demolished in November $2014 .^{3}$

In this room, and at this table, Baldwin labored over his last two novels, different yet interlinked tales about black domesticity, published within five years of each other: If Beale Street Could Talk (1974) and Just Above My Head (1979). He also worked there on his last volume of essays, which discussed the Atlanta children murders, The Evidence of Things Not Seen (1985). Its last page names the multiple locations where Baldwin took its developing manuscript as he traveled and taught in the 1980s-Atlanta, New York, Amherst, St. Paul-de-Vence. This book, about which the late Amiri Baraka says, "That's some high-speed, elegant speech, but the activism in that ... the actual popping of these people up the side of the head is remarkable," exerted a heavy emotional and physical toll on the writer. This can be seen in the volume's breathless, staccato, and at times raging tone, and in the thick files of documentation and Xeroxed pages Baldwin amassed while researching it. ${ }^{4}$ While the majority of Baldwin's contemporaries misread the intensity and passion of this text, attributing their discomfort with reading it to the writer's waning powers, new scholarship offers astute analyses of this coda to his published nonfiction, as well as his last two novels, as testaments to the generative nature of his last authorial abode. ${ }^{5}$

The complex, exciting cluster of paradoxes that is James Baldwin inspired my book, Me and My House: James Baldwin's Last Decade in France. My experience, memories, and impressions of what used to be his dwelling- "Chez Baldwin," as it has been known locally-inflected my scholarly toolkit. In this essay, I trace some stages of the conceptualization of this project and the mapping of my literary critical approach, both of which have been compelled by my access to a complex and unexpected archive of material objects left over from the writer's house. ${ }^{6}$ These abandoned objects-some furniture, a spare electric typewriter, pieces of scribble-filled paper, bills, and art, as well as books, journals, magazines, files of Xeroxed pages, vinyl records, and clippings that spilled over shelves and desktops throughout the house-were the only material archive remaining after Baldwin's death in 1987. I was astounded that no one in his family wanted to claim them, yet also understood that scholarly desires for material preservation are often at odds with those of estates, lawyers, and kin, not to mention archives and libraries that value only manuscripts and authenticated traces of the author's "hand." I am incredibly fortunate to have been able to see and document some of these material traces in my book on the inseparability of Baldwin's domestic and creative imaginations. 


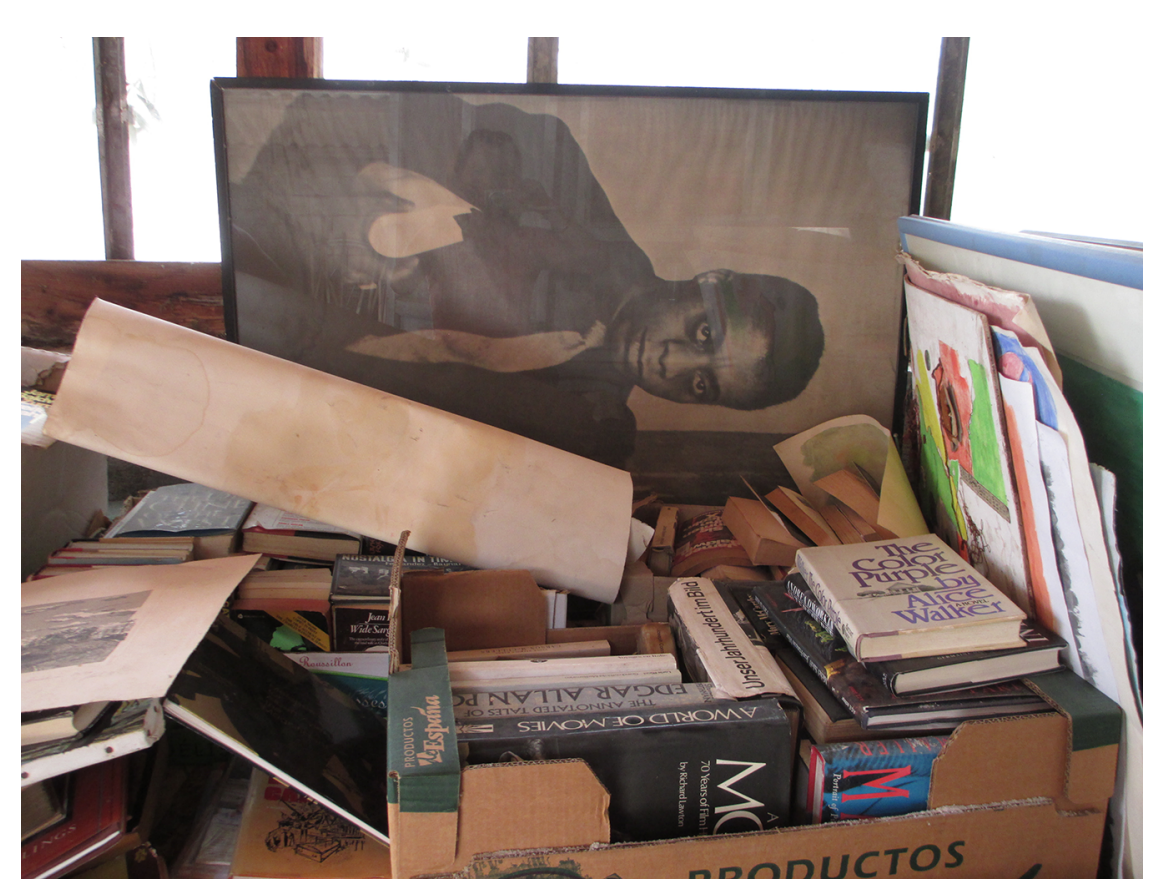

Figure 2 Chez Baldwin Archive: Baldwin's portrait and books in the storage area. Photo by author, 2014

In terms of literary critical resources, the eclectic archive that has inspired my project weaves in and out of Baldwin's writings, biographies, testimonies of friends and relatives, unpublished letters, interviews in various formats-including those on the Internet-and whatever remains of his widely conceived and still largely inaccessible legacy. As part of that legacy, I also engage with photographs that I took and impressions of his house in St. Paul-de-Vence in France that I wrote during my first visit there in 2000, as well as the leftover objects mentioned above that I was allowed to research in 2014 and thoroughly documented in 2017. The inseparability of the material and metaphorical in his writings and life story therefore underpins this essay, which argues for the importance of Baldwin's connection to things and spaces in reassessing his complex legacy, especially his contribution to writing and rewriting the conundrum of black domesticity, whose full impact on U.S. history and culture we have yet to acknowledge.

As Me and My House does on a larger canvas, this essay centers the juxtaposition of self and domicile, individual and social space, and body and architecture, while examining the material and metaphorical, or literal and literary, traces of this writer's domestic life within and beyond the United States. ${ }^{7}$ Emphasizing the cyclical nature of the evolution of Baldwin's ideas about the intersections of social space, representations of the self, and the stories we tell about both, it travels among actual geographical and physical locations, the pages of his published works, interviews, 
and unpublished letters, memories he left with friends and family, and the archive of objects salvaged from his house in St. Paul-de-Vence. My immediate goal is to show how Baldwin challenged, revised, and at times exploded the conventions of racialized domesticity in the United States, and of national and African-American cultural and literary histories. My longer-term goal is to tap into the longing and desire to preserve, to the degree that a project like this allows, what remains of the matter and stories of the domestic life of James Arthur Baldwin. A pivotal and unique figure in American literary, social, and cultural history, Baldwin left a scarce material legacy that is only now beginning to be memorialized: a meager collection of his papers is available at a handful of libraries, and some of his works - and certainly his letters-remain unpublished or out of print. The large archive of manuscripts recently sold by the Baldwin Estate to the Schomburg Center for Research in Black Culture in New York City is available only to credentialed scholars; the public must wait twenty years before this material can be published. By now there are a few historical markers honoring Baldwin in New York City's Harlem and Greenwich Village neighborhoods. Still, there is no writer's house or museum devoted to him anywhere, even in France, where he found his most beloved home in late life. This absence and scarcity-not surprising given how few African-American writers' houses are open to the public in the United States, and that, halfway through the second decade of the twenty-first century, the National Museum of African American History and Culture has only recently opened-only compound Baldwin's material and metaphorical "homelessness." Much like those of countless other black Americans that the new museum honors without naming, his legacy remains in flux, the material traces of his life almost completely erased from his home country.

Despite this sad state of affairs, Baldwin's call to honesty and confession prompts me to celebrate him as an extraordinary person and artist whose legacy should be recognized as every American's ancestral right. Closely reading his fragmented impressions of moments when the self comes into contact with social space to tell stories both in his texts and life sheds light on the remnants and refuse of Baldwin's legacy. What these remnants have taught me is that, like writers, critics, too, must dwell "within the experience and outside of it at the same time," as Adrienne Rich suggests, overlaying what can be known with honest, careful, and hard-won interpretation and analysis. ${ }^{8}$ This approach has also mandated a weaving of biographical material and, indeed, matter, occasionally even auto-ethnography, into my literary analyses. Prompted by Baldwin's own reliance on life writing, by the embrace of such writing by black women writers like Maya Angelou, Audre Lorde, Alice Walker, and Jamaica Kincaid, and by some of the tenets of New Materialism, I combine Baldwin's auto-scrutiny and self-reflectivity with the value and meaning of "ideas ... in things," as inspired in part by William Carlos Williams's famous lines. ${ }^{9}$

In the three movements that follow, I proceed from a reading of Giovannis Room and some essays, through biographical elements pertaining to Baldwin's life in St. Paul-de-Vence, to the importance of interdisciplinary, dialogic, and digital approaches to studying domestic practices of non-normative transnational subjects 
of color, and especially black queer ones like Baldwin. My goal is to show that the legacy James Baldwin created in his beloved house in St. Paul-de-Vence is both a literary and cultural one and a manifesto for the humanities in all shapes and forms today. Documenting his archive is a welcome challenge to the emergent field of Digital Humanities. Baldwin's lesson on embracing the personal as always political, and as pertaining to intersectional humanity, provides the only way for the diverse populations of the U.S. national house to finally feel at home in it. ${ }^{10}$

\section{The Book of the Matter}

"Perhaps home is not a place but simply an irrevocable condition," Baldwin wrote in his second novel, Giovanni's Room, in 1956, his narrator's voice metaphorically linking his literary characters' and his own experiences of exile to those of immigrants and migrants throughout the world. ${ }^{11}$ David, a sexually conflicted and repressed white American, and Giovanni, a displaced southern Italian, meet in Paris, fall in love, and cohabit in a symbolically loaded "room." ${ }^{12}$ For the American, in Europe supposedly to "find" himself, the room becomes a closet associated with homosexuality, from which he tries to flee and which he cannot bring himself to embrace. For the Italian, who cannot ever return home, and who accepts his fluid sexuality unequivocally-he calls it the "stink of love"-the room is a space of desire, liberation, and redemption. ${ }^{13}$ Because David and Giovanni share neither a story nor a spatial vision of their connection, and can neither understand nor see each other as products of Old and New World cultures, their relationship is doomed from the start. Blind to the ways in which he has inherited from his ancestors-those whites-in-the-making who "conquered a continent, pushing across death-laden plains ... to an ocean that faced away from Europe into a darker past"-Americanbred tales of homophobia and racialized gender bipolarity, David loses his only chance for love, self-discovery, and self-acceptance. By breaking his heart and leaving him, he also causes Giovanni's tragic end. ${ }^{14}$ However deliberately sensational its plot's reliance on an actual event in New York, this novel's racialized and sexualized recounting of what Nina Baym has termed the "melodramas of beset manhood" is powerful evidence of the ways identity is undergirded, created, and represented in complex relation to narrative and social spaces. ${ }^{15}$

Baldwin's reliance in Giovanni's Room on tracing the ways in which social spaces, and private dwellings especially, expose links between identity and its gendered, racialized, and sexual representations at home and abroad confirms his engagement with what William Gleason has termed "architectural features of narrative space." 16 Baldwin takes this type of spatial storytelling on a transatlantic journey in a scene where Giovanni counters David's naïve belief that he can go back home to America: "You don't have a home until you leave it and then, when you have left it, you never can go back." ${ }^{17}$ When David insists that his is a special case, that, as an American, he can avoid the consequences of his actions, Giovanni jokes, "You ... remind me of the kind of man who is tempted to put himself in prison in order to avoid being hit by a car." ${ }^{18}$ To Giovanni, an economic migrant from southern Italy who has left 
his wife and village, never to return, David's desire to isolate himself from same-sex sexual passion, to dwell in the heteronormative world of his white American father, to remain "clean," as Giovanni tells him bitterly, is both a tragic flaw_-"You do not love... anyone!"- -and a lethal weapon - "You want to kill him [Giovanni] in the name of your lying little moralities."'19 Baldwin's evocative metaphor of the prison in this novel is apt for the American national house and men like David, for its prescriptions for manhood have so fully colonized his mind and body that he cannot find "himself" anywhere: he cannot even envision, much less accept, his identity in full. Thus incarcerated in/by his sexuality, he is left impotent as a subject. What David realizes at the end is that he will never be free of memories of Giovanni and their affectively loaded room, no matter how far away he escapes from both. Hence Baldwin's novel can be read as recounting the impossibility of white American male domestic desire both at home and across the Atlantic.

David's homelessness-as a man exiled from American notions of patriarchal, thus heteronormative and white manhood because of his desire for sex with other men-can be read in the context of what Claudia Tate terms "the political desire... [for] the acquisition of authority for the self both in the home and in the world." ${ }^{20}$ While Tate builds this paradigm reading post-Reconstruction black female texts, it works surprisingly well for David's story in Giovanni's Room once we realize that this seemingly "all-white novel" is in fact all about race, gender, sexuality, and various domestic spaces that are both public and private, national and international. David's sense of exclusion from his home country, and especially from his father's rigidly defined "manly" U.S. house, is exacerbated by the impossibility of his ever truly "playing house." Try as he might-and as he did, briefly, with his American fiancée, Hella-he would never become a proper American "husband."

The day David meets and falls for Giovanni, that discovery is juxtaposed with a fleeting image of a black man, or one who appears black to him, seen from a cab window. Looking "beyond... [Giovanni's] heavy profile," and contemplating the fog hanging over the city as they drive through it, David sees the otherwise pearly soft mist "clinging like a curse to the men who slept under the bridges-one of whom flashed by beneath us, very black and lone, walking along the river" (emphases added). ${ }^{21}$ That homeless black man, cursed in the way the biblical progeny of Ham was forever cursed, is David's dreaded other and the flip side of Giovanni, who might have stepped off the pages of Ellison's Invisible Man. He is the one who David fears he will become if he lets his secret out: "I was in a box for I could see that, no matter how I turned, the hour of confession was upon me."22 The truth of one's identity cannot be escaped, even if one forces oneself to become a prisoner of a model version-and David's American whiteness so encages him that he cannot conceive of himself otherwise. As Baldwin explained in a 1984 interview with Mavis Nicholson, his protagonist's central failure is an inability to feel: "If you can't love anybody, you're dangerous." ${ }^{\text {23 }}$

Read closely, many works throughout Baldwin's oeuvre, like Giovanni's Room, can be seen as engaging various manifestations of domesticity: material and metaphorical, spatial and ideological, gender- and genre-related, religious and 
secular, and indeed literal and literary, as well as embodied and psychological. From the examination of African-American home lives between the North and the South and within the spiritually and erotically charged spaces of the black Pentecostal church and New York City's streets in Go Tell It on the Mountain (1953); through that city's landscapes infused with interracial desire, contingent on southern and French homoerotic domestic locations as well as queer homelessness in Another Country (1962); to the portrait of an artist as a black man with no place to put down roots in Tell Me How Long the Train's Been Gone (1968); to examinations of black families' and artists' tragic negotiations of private and public spaces within and beyond the United States in If Beale Street Could Talk (1974) and Just Above My Head (1979) - Baldwin's novels explore manifestations of what could be called the black house and home. Deploying his experience as a lower-class child from Harlem, and later an accomplished writer who had to configure his domestic spaces around the challenges of his writing, activism, travel, and economic needs, Baldwin infused many of his essays with metaphors of domesticity that confirmed his commitment to the private being always political and vice versa. Last but not least, his three plays, The Amen Corner (1954, 1968), Blues for Mister Charlie (1964), and The Welcome Table (unpublished), dramatized powerful instances of desire for utopian domesticity, and of family conflict as the backdrop for gendered and racialized intergenerational struggle and conflicted national identity.

\section{The Material of Life}

Baldwin's need to sort out the autobiographical meanings of his own national house and of personal home spaces in essays, novels, plays, and even his few poems arises as much from his desire to reconfigure his identity as a black queer American as from a larger intellectual project to reinterpret the concept and problem that W. E. B. Du Bois famously named the "color line." Along with that project, Baldwin's writings explored and exploded the meanings of "blackness" and "home" as historical, economic, social, and cultural creations and representations, products, and constructs located in social space. I read his project as rearticulating and redefining Du Bois's "problem of the twentieth century," or the "color line" from The Souls of Black Folk (1903), by means of what Baldwin refers to in the essay "Every Goodbye Ain't Gone" (1977) as the "demarcation line" between the things that "happened to me because I was black ... and ... things [that] had happened to me because I was $m e$ " (emphases added), ${ }^{24}$ hinting at theoretical approaches to identity that would arise in U.S. and European academes in the decades following the publication of his works.

In "Every Goodbye Ain't Gone," his task is to disentangle black from me. He sets out to "perceive, define, a line nearly too thin for the naked eye, so mercurial, and so mighty," or the tenuous space between black and me that makes him "study the hieroglyphics of my circumstances," as the only way to "decipher my inheritance."25 Within its few pages of intense, frenzied prose, the essay illuminates the meaning of "Ezekiel's wheel in the middle of a wheel, with the iron, inescapable truth 
of revolutions-we black folk say what goes around, comes around." 26 That is, the essay arrives at the realization that has cycled for Baldwin for nearly three decades as he has written diverse works and searched for answers all over the world, the realization that brings home, blackness, and me together in terms of his authorial experience, its perceptions, and its cost:

There was a demarcation line, to be walked every hour of every day. The demarcation line was my apprehension of, and, therefore, my responsibility for, my own experience: the chilling vice versa of what I had made of my experience and what that experience had made of me. ... I have been in and out of my country, in and out of various cauldrons, for a very long time, long enough to see the doctrine of white supremacy return, like a plague, to the continent which spawned it. ... Every goodbye ain't gone: human history reverberates with violent upheaval, uprooting, arrival and departure, hello and good-bye. Yet, I am not certain that anyone ever leaves home. When "home" drops below the horizon, it rises in one's breast and acquires the overwhelming power of menaced love. ... My ancestors counseled me to keep the faith: and I promised, I vowed that I would. ${ }^{27}$

Baldwin's national house, the United States, is where a larger history takes place and where he would not live permanently ever again. Immersed in that history, a singular life like his has a cyclical quality of intimation, experience, and confirmation of thus extracted knowledge: "I suspect, though I certainly cannot prove it, that every life moves full circle-toward revelation: You begin to see, and even rejoice to see, what you always saw," he explains at the end of "Every Goodbye Ain't Gone." ${ }^{28}$ That first trip away from his native country and place of birth set up a pattern for the rest of his life.

Baldwin's lack of sustained domestic life in the United States, beyond his difficult youth, and his more successful attempts in other places reveal that "anguish" is integral to being homeless, in exile, and it follows one wherever one may travel: "[It] has your number, knows, to paraphrase the song, where you live. It's a difficult relationship, but mysteriously indispensable. It teaches you." ${ }^{29}$ The U.S. national house, however hostile to black queer men with artistic inclinations like Baldwin, also contains the home where his family lives, where he was born, where his people have made their place for better or worse for generations, where, indeed, one must keep the faith and accept anguish as part of the bargain. Hence when the writer comes back "to the eye of the hurricane," he is still menaced and metaphorically homeless in the country of his origin, but he now has his craft-which he uses like a shield, and which enables him to stay a while. Now at last, having written works beyond his first novel, Go Tell It on the Mountain- "All my love was in it, and the reason for my journey"-and having returned as an established literary figure, his personal story of "that dreadful day of November of ' 48 is redeemed."30

Yet despite Baldwin's erudite theorizing of the American writer's creative problem throughout his career, it is not until the later essays of his last two decades that he reconciles multiple attempts to fully embrace himself as a complex composite 
of fragments, reflections, and often confounding intersectional and gendered personas whose choices and freedoms could never be taken for granted. ${ }^{31}$ Only in his late works does he accept himself as someone who has had to delve deeply into his own "level of the private life," as he terms that realm in "Notes for a Hypothetical Novel" (1960), to become, as he states in the introduction to Notes of a Native Son, "an honest man and a good writer." ${ }^{2}$ In racialized and gendered terms, such a trajectory defies the simple narrative of white masculine progress toward power and recognition that passes for the so-called American Dream. ${ }^{33}$

The theme of self-discovery and acceptance, of puzzling his own self out of disparate fragments, intertwines in Baldwin's later works with the theme of violence lurking around, blurring, or obscuring interrelated key aspects of identity-race and sex. All of this takes place at the heart of gendered performances of national identity seen as both individual and collective enactments of self at home. ${ }^{34}$ This complex struggle comes to the fore especially clearly in another essay published thirty-six years after "Everybody's Protest Novel" and a quarter-century after "Notes for a Hypothetical Novel"- "Freaks and the American Ideal of Manhood" (1985), later retitled “Here Be Dragons." Baldwin looks back at his teenage years and early twenties, which he spent away from his family in Harlem, working odd jobs and desperately trying to become a writer in Greenwich Village. Writing from the perspective of having recently entered the seventh decade of his life, he recalls feeling "the youngest, the most visible, and the most vulnerable" there:

There were very few black people in the Village in those years, and ... I was decidedly the most improbable. Perhaps, as they say in the theater, I was a hard type to cast. . . I felt absolutely, irredeemably grotesque. ... It wasn't only that I didn't wish to seem or sound like a woman, for it was this detail that most harshly first struck my eye and ear. I am sure that I was afraid that I already seemed and sounded too much like a woman ... a sissy. It seemed to me that many of the people I met were making fun of women, and I didn't see why. I certainly needed all the friends I could get, male or female, and women had nothing to do with whatever my trouble might prove to be [emphases added]. ${ }^{35}$

Right before this confession, he also remembers "the queer-not yet gay-world" he then entered, and he compares his situation to finding himself in a "hall of mirrors," or an "even more intimidating area" of self-estrangement, for "the mirrors threw back only brief and distorted fragments of myself." 36

This poetic way of conveying his youthful confusion about racialized gender and sexual identity resonates with his sense of never fitting in, of feeling homeless, lost, and conspicuous, "impossible," even "grotesque," as a young black man filled with homoerotic desire and freshly removed from Harlem, which was home, but where he suffered from homophobia and at the hands of his stern step-father and racist police. He relays a similar sentiment in an interview, "Go the Way Your Blood Beats," with Richard Goldstein, published in 1984 in The Village Voice, a year before the essay "Freaks" appeared in Playboy magazine and took those sentiments 
further. Read together, the interview and essay record a culmination of Baldwin's thinking on identity and identification that he explored until the end of his life, especially in the underappreciated essay volumes No Name in the Street, The Devil Finds Work, and The Evidence of Things Not Seen; his last two novels, If Beale Street Could Talk (1974) and Just Above My Head (1979); and his last play, The Welcome Table (unpublished).

In 1984, three years before his passing, Baldwin distanced himself from nostalgia in an interview - "I don't feel there are any ghosts, any regrets" - seemingly dismissing the weight of the past. ${ }^{37}$ Two years later, he affirmed the necessity of life writing and recycling the past creatively in his art: "I don't know whether you can hunt more and more of your own life or if more and more of your own life will hunt you, but it comes back to you during points in your life in another light." ${ }^{\prime 38}$ As Adrienne Rich inimitably sums up his legacy in "The Baldwin Stamp": he "could be viewed as apocalyptic preacher, as instigator to black rebellion, as provoker of 'white guilt' (a concept he in fact devastatingly dissected)." ${ }^{39}$ She praises his staunch insistence on remaining "a real writer and not a mere celebrity or appointed spokesperson," admitting that such a stand did not win him an easy place in the literary pantheon, as "he was hailed (and attacked) as an early writer of fiction on homosexual experience; criticized harshly for living in Europe while writing on America, for being too much the 'aesthete' or too much the engaged writer." ${ }^{40}$ Most important, he showed us that "the artist needs to dwell 'within the experience and outside of it at the same time," turning his "own awareness of this difficult positioning" into "a supreme artistic strength."11 Rich's words ring especially true today, for while "his country has put his face on the first-class postage stamp... [it] has yet to face its own confusion in his art's unsparing mirror." ${ }^{42}$

Baldwin remains unmatched at juggling contradictions and explicating conundrums of a humanity that is always intersectional and paradoxical. He recast the ways Americans of all hues viewed themselves and others, how they loved, had sex, and dwelled in their homes, countries, and the world decades before scholars could fully comprehend his message. In his complex vision, memory and self are always spatially contingent; time works cyclically, and identity, like desire, is an unpredictable vortex of complex processes happening as much on material as immaterial planes. Fierce creativity ensues, and mysterious, uncontrollable nooks and crannies of the expansive and wondrous imagination fill with music, pictures, and sensations of the ever-present body that writes down what it feels.

\section{The Object as Metaphor}

As Toni Morrison reminds us, echoing Baldwin,

There are only versions of ourselves, many of which we have not embraced, most of which we wish to protect ourselves from. For the stranger is not foreign, she is random; not alien but remembered; and it is the randomness of the encounter with our already known-although unacknowledged—selves that summons a ripple of alarm. ${ }^{43}$ 
Having proclaimed Baldwin her literary father figure in her eulogy at his funeral, Morrison speaks of the power that language and image have over human experience and, in effect, how we see, perceive, and treat others. What I have found in reading both of these writers is that Baldwin's version of humanism was often too expansive and revolutionary for those who did not acknowledge their multiple sites of difference. His black queer humanism, for that is what his prolific career has bequeathed us, profoundly transformed Western humanism through the lens of the African Diaspora, and specifically black experience within and beyond the United States.

Baldwin's inspirations that came from objects, and especially the visual arts, could be seen in his fondness for collage, which was clear in many of the places he occupied-he had various assemblages of images, clippings, objects, and sketches wherever he lived, especially in Turkey and France in the 1960s, 1970s, and 1980s. Many of Baldwin's friends with whom I have spoken have confirmed that the writer was a consummate aesthete: he loved fine clothes, colors, and textures, quality fabrics, and interesting jewelry; his house was filled with tasteful furniture, rugs and throws, pillows, and knick-knacks. His love of music manifested in a large vinyl collection that has survived both him and his brother David, who lived in the house until 1996. A corkboard in Baldwin's office that was reproduced in a magazine ${ }^{44}$ had the jackets of his last books-The Price of the Ticket and The Evidence of Things Not Seen-pinned next to photographs of friends and family; a white cast of Pascal's death mask leaned against the wall underneath the board. Baldwin liked to fill his dwelling spaces with comforting, trivial objects. In an unpublished letter to David Leeming, written from Istanbul on 27 December 1965, he referred to them as "little gimcracks, like mirrors, and ash-trays." ${ }^{45}$

While reflecting his aesthetic predilections, Baldwin's love for collages and assemblages also mirrored his writing style, especially those works he created during the underappreciated decades of the 1970s and 1980s. By that time, the visual and material inspirations introduced to him by his Greenwich Village mentor and surrogate father figure, the painter Beauford Delaney, along with the musical rhythms, improvisations, and avant-garde harmonies he admired in blues and jazz pioneers like Bessie Smith, Miles Davis, Nina Simone, and Charlie Parker, inspired mature, complex, and sometimes experimental narrative forms. ${ }^{46}$ These daring stylistic and compositional arrangements could be discerned already in his third novel, Another Country, and they certainly animate his later work. They are especially powerfully executed in the syncopated dialogues and call-and-response riffs propelling his play The Welcome Table, whose genesis goes back to Turkey and whose setting is literally within the very walls of his house in St. Paul-de-Vence.

To this critic, Baldwin's literary mastery, in all its shapes and forms, and with all its demanding density and complexity, is unparalleled in twentieth-century American letters. That mastery was the result of a complex nexus of events and influences that would have taken a much longer lifetime than his to fully gestate and flourish. It came from a process that was seldom painless, often excruciating, and far from completion at the time of his death from cancer in 1987 , when he was only 63 . I have said this more than once in my earlier work on this writer, but it bears repeating 
that Baldwin's writing life was a continuous fluctuating process, an ebb and flow of experimentation and honing of his style that repudiates the unhelpful cleaving of his oeuvre into pre- and post-Fire Next Time periods of ascendancy and decline that still holds sway over some critics and scholars. At the center of this process, the part that took place over the last decade and a half of his life in 1971-87, stands his domestic abode in St. Paul-de-Vence. It is from that materially and metaphorically loaded location that Me and My House set out to reconstruct and demonstrate the centrality of Baldwin's ideas on home, both to his writing and to his rich legacy as one of the greatest American authors, witnesses, and prophets. ${ }^{47}$

The research process that has taken me from the first glimpse of the house to the finished book has been as much dictated by the demands and challenges of the Chez Baldwin archive as by my own limitations as a literary scholar more comfortable among paper than e-books and with handling paper photographs rather than taking digital ones herself. Herein lies one of the most important lessons that Baldwin has taught me, one that provided the title for this essay, and that I am now using to frame its conclusion: "You have to get to where you are before you can see where you've been." ${ }^{38}$ With Me and My House, I have arrived at being able to employ the approaches of Digital Humanities to document and learn from Chez Baldwin, because there was no other way to do it. Once I realized I could do it, however imperfectly, I also came up with the idea of creating a virtual writer's house-museum for Baldwin, which will become a digital companion to the book. ${ }^{49}$

As Baldwin writes in many of his essays, there are racial and sexual secrets and myths undergirding American cultural and social history that sharply cut across racial and class lines (myths that have been revived with frightening persistence in our own time). Queer domestic life, not to mention doubly marginalized black queer or queer of color homemaking, have been long-term taboos in U.S. culture. It is therefore crucial to notice that Baldwin's later works show us how the official, traditional representations of how black and white Americans have envisaged domesticity since the mid-twentieth century have been superficial, small-minded, and provincial at best. Crafted to uphold the ideal of the national house, they may let us, for example, learn about Alice B. Toklas and Gertrude Stein. But since these eccentric women lived as lesbians in Paris and not in Pittsburgh, we are supposed to chalk their lives up to having been inflected, if not tainted, by foreign, indeed, perverse "European" freakishness. Such expulsions of gender and sexual identity beyond the borders of the national house in the portrayals of cultural icons like Baldwin strip them of their complexity and adulterate their art. For example, even in the recently popular Raoul Peck art film, I Am Not Your Negro, we encounter the so-called "Baldwin brand," or the desexualized race man, rather than the intersectionality-promoting radical who exploded binaries of identity, and by 1985-87 advocated for domesticating androgyny and black queer sex both in his works and on the pages of Playboy magazine. ${ }^{50}$ To those who would not accept him even today, and there are many, the radical better remain hidden at Chez Baldwin. 


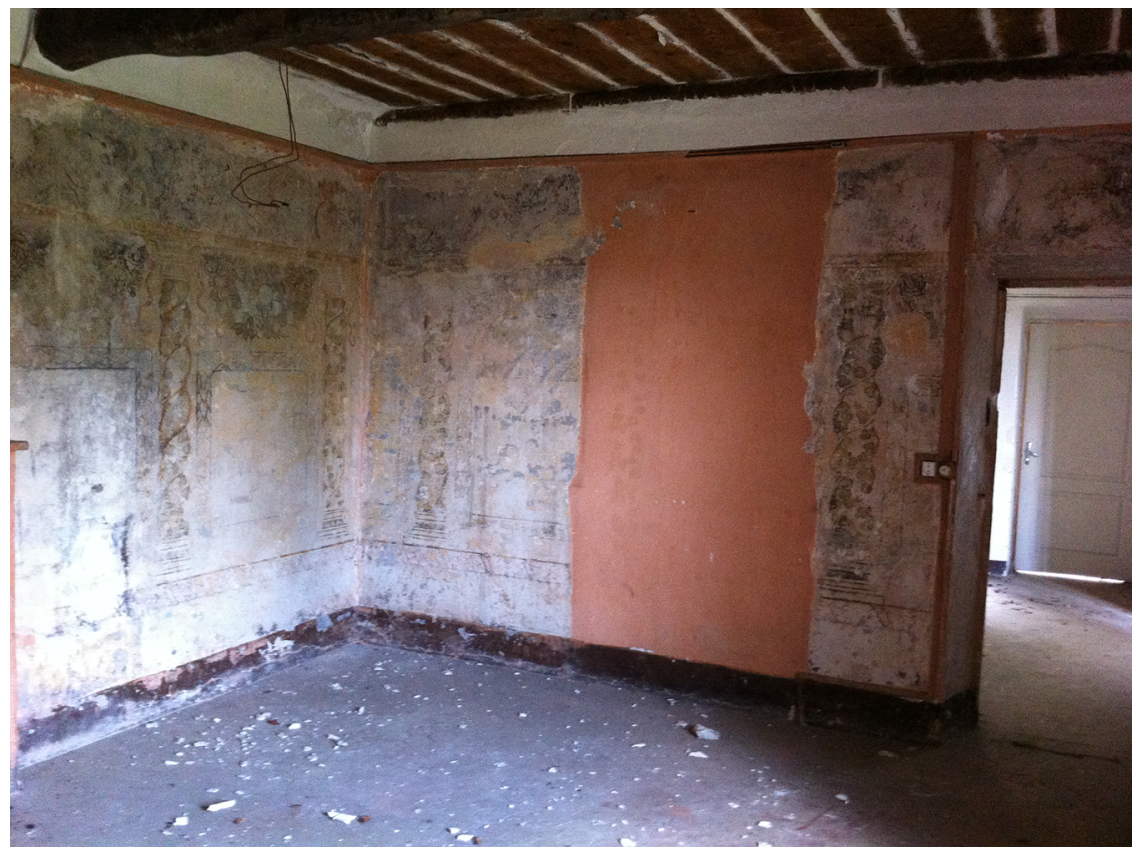

Figure 3 Chez Baldwin. The last room, where Baldwin died. Photo by author, 2014

Another issue that has loomed large in my work process has been that of class, or how to interpret Baldwin's changing economic circumstances. Some of Baldwin's readers used to think, and perhaps still do, that it is somehow uncool that, in his later life, the activist Baldwin who came from dire poverty in Harlem was a bourgeois owner of a fancy property in Provençe, where he entertained lavishly and kept younger lovers in addition to an entourage of hangers-on. This attitude may have something to do with the long history of the politics of respectability on both sides of the proverbial U.S. color line. Along with the stifling, binary, hetero-patriarchal, misogynist, mainstream social norms that often masquerade as patriotism, nationalism, or ethnocentrism, that attitude made Baldwin an outcast and rendered him, in a sense, again homeless in the United States. Baldwin, of course, being who he was, wrote vehemently against all these oppressive politics in his later works.

I wish we could all be happy for Baldwin's rags-to-riches story today and celebrate the fact that he found a haven where he was cherished and nurtured and wrote some of his most interesting work. As many of his letters to friends and family show, he was acutely aware that his portrayal of queer and interracial love and sex in Another Country and Just Above My Head not only angered, but also threatened both black nationalists, who despised his sexuality and integrationist 
views, and so-called white liberals, who objected to his candor concerning their complicity in national race relations and what they perceived as his "black anger." These later works are daring in terms of content, narrative structure, characterization, and imagery. They reveal a writer growing and experimenting, unafraid to test new waters. Baldwin considered his last novel his best, for example. I agree, for the more one reads Just Above My Head, the more its formal and thematic radicalism becomes clear and compelling-move over postmodernism. Another matter is that reading late Baldwin requires work and the intellectual willingness to be challenged, if not changed. You cannot encapsulate any of his ideas in 140 characters; you have to fight for who you can become thanks to his literary witnessing. That's what great literature has always done, and that's why we find his writings so relevant to our racially and politically troubled moment today. His vision of home endures and unites; we would do well to dwell in it with all our hearts.

\section{Notes}

1 Interview with Kay Bonetti, 1984, www.youtube.com/watch?v=dua3dtrvq84 (accessed 21 October 2015). Baldwin talks about writing essays to "clarify my reality," and to "feed" his fiction; this is a response to critics' opinions that he is a better essayist than a novelist. See also www.youtube.com/watch?v=XxCV-_8Two0 (accessed 16 July 2016), where Baldwin reads from Just Above My Head (recorded in April 1984 when he was teaching at Amherst).

2 Bill Mullen mentioned this Arab connection, first cited by me in James Baldwin's Turkish Decade: Erotics of Exile (Durham, N.C., Duke University Press, 2009), in his keynote address at the International James Baldwin Conference at the American University in Paris on 28 May 2016. Raoul Peck's film on Baldwin, I Am Not Your Negro (2016), has a screenplay based on the manuscript, or treatment, of "Remember This House" that Baldwin left among his papers. Peck was granted access to this document by the estate, a privilege that I have been denied. See also the book version, James Baldwin and Raoul Peck, I Am Not Your Negro (New York, Vintage, 2017).

3 My latest communication with Les Amis de la Maison-Baldwin confirms that the final part of the house has been recently lost. The "last room," a frescoed former dining room on the first floor in which the writer died, will become a posh spa in a complex of expensive villas currently being sold by Sotheby's. Personal correspondence, 17 March 2018. https://lamaison-baldwin.org/ (accessed 13 June 2018).

4 See the C-SPAn clip with Amiri Baraka in "James Baldwin's Literary Legacy," www.cspan.org/video/?c2848533/clip-james-baldwins-literary-legacy (accessed 13 June 2018).

5 See, for example, D. Q. Miller, Re-Viewing James Baldwin (Philadelphia, PA, Temple University Press, 2000); Lawrie Balfour, The Evidence of Things Not Said: James Baldwin and the Promise of American Democracy (Ithaca, N.Y., Cornell University Press, 2001); and E. F. White, "The Evidence of Things Not Seen: The Alchemy of Race and Sexuality," in L. King and L. Scott (eds.), James Baldwin and Toni Morrison: Comparative Critical and Theoretical Essays (New York, Palgrave, 2006), pp. 239-60. This text is also echoed in Morrison's "Unspeakable Things Unspoken: The Afro-American Presence in American Literature," which later became Playing in the Dark: Whiteness and the Literary Imagination (New York, Vintage, 1993). 
6 I am grateful to Jill Hutchinson, the life partner of the late David Baldwin, James's younger brother and the manager of his affairs and the house until 1996, for letting me access and document this archive. Hutchinson rescued these materials, which, abandoned by the Baldwin family, would have ended up in the trash, around the early 2000s, when the property was lost to developers. Baldwin's manuscripts and letters were removed shortly after his death by his biographer, David Leeming. Thanks are due to the University of Michigan's College of Literature, Science, and the Arts, its ADVANCE program, as well as my academic home departments, American Culture and Afroamerican and African Studies, for their assistance in and financial support for my research on this project.

7 Melvin Dixon's Ride Out the Wilderness: Geography and Identity in Afro-American Literature (Champaign, IL, University of Illinois Press, 1987) is among my early inspirations, along with a passage from Ralph Ellison's Shadow and Act (New York, Vintage, 1995) that Dixon includes in his introduction: "If we don't know where we are, we have little chance of knowing who we are, that if we confuse the time, we confuse the place; and that when we confuse these we endanger our humanity, both physically and morally" (Ellison, Shadow and Act, p. 74, quoted in Dixon, Ride Out the Wilderness, p. 2).

8 Adrienne Rich, “The Baldwin Stamp," in A Human Eye: Essays on Art in Society, 19972008 (New York, W. W. Norton, 2010), pp. 55-6.

9 William Carlos Williams's famous dictum for poetic expression can be found in his 1927 epic, "Paterson." See also Timothy Morton, Hyperobjects: Philosophy and Ecology after the End of the World (Minneapolis, MN, University of Minnesota Press, 2013); Elizabeth Grosz, "Feminism, Materialism, and Freedom," in Diana H. Coole and Samantha Frost (eds.), New Materialisms: Ontology, Agency, and Politics (Durham, N.C., Duke University Press, 2010), pp. 70-91; and Diana Coole, "Inertia of Matter," in Coole and Frost (eds.), New Materialisms, pp. 92-115.

10 In the book, I expand on how he forged and affirmed these new approaches to identity alongside the black feminists and writers at the time.

11 James Baldwin, Giovanni's Room (New York, Vintage, 2013), p. 121.

12 My first essay on this novel introduces this theme: Other Americans, Other Americas: The Politics and Poetics of Multiculturalism (Aarhus, Aarhus University Press, 1998).

13 Baldwin, Giovanni's Room, p. 187.

14 Ibid., p. 64.

15 Cass Adair, a Ph.D. candidate at the University of Michigan, drew my attention to the New York Times account of that event: Frank S. Adams, "Columbia Student Kills Friend and Sinks Body in Hudson River," 17 August 1944. See also Zaborowska, Other Americans, Other Americas, and "From Baldwin's Paris to Benjamin's," in Gevork Hartoonian (ed.), Walter Benjamin and Architecture (New York, Routledge, 2009), pp. 51-74. See also Nina Baym, "Melodramas of Beset Manhood: How Theories of American Fiction Exclude Women Authors," American Quarterly, 33:2 (1981), pp. 123-39, and Stephanie Brown and Keith Clark, "Melodramas of Beset Black Manhood? Meditations on African American Masculinity as Scholarly Topos and Social Menace: An Introduction," Callaloo, 26:3 (2003), pp. 732-7.

16 See William Gleason, Sites Unseen: Architecture, Race, and American Literature (New York, NYU Press, 2011), pp. 26-7.

17 Baldwin, Giovanni's Room, pp. 154-5.

18 Ibid., p. 155.

19 Ibid., pp. 185, 186, 187. 
20 Claudia Tate, Domestic Allegories of Political Desire: The Black Heroine's Text at the Turn of the Century (Oxford, Oxford University Press, 1993), p. 8.

21 Baldwin, Giovanni's Room, pp. 61-2. I am grateful to Douglas Field for his editorial advice and comment on this quotation as referring to the biblical curse of Ham.

22 Ibid., p. 64.

23 “Civil Rights. James Baldwin Interview. Mavis on Four," Interview with Mavis Nicholson, www.youtube.com/watch?v=UXLDS8XQXHU (accessed 3 August 2017).

24 James Baldwin, The Price of the Ticket: Collected Nonfiction 1948-1985 (New York, St. Martin's Press, 1985), pp. 642-3.

25 Ibid., pp. 643, 644.

26 Ibid., p. 644.

27 Ibid., pp. 645-67.

28 Ibid., p. 646.

29 Ibid.

30 Ibid., pp. 646, 647.

31 See Douglas Field, All Those Strangers: The Art and Lives of James Baldwin (Oxford, Oxford University Press, 2015).

32 James Baldwin, Notes of a Native Son (Boston, Beacon Press, 2012), p. 9.

33 Ta-Nehisi Coates's Between the World and Me (New York, Random House, 2015) neither fully recognizes nor acknowledges extensive borrowings from Baldwin's The Fire Next Time (New York, Vintage, 1992).

34 See Lauren Rusk, The Life Writing of Otherness: Woolf, Baldwin, Kingston, and Winterson (New York, Routledge, 2009), where Baldwin appears as a "writerly" author in the company of the women writers Woolf, Kingston, and Winterson.

35 Baldwin, The Price of the Ticket, pp. 684, 685.

36 Ibid.

37 Fred Standley and Louise Pratt (eds.), Conversations with James Baldwin (Jackson, MS, University Press of Mississippi, 1989), p. 250.

38 Standley and Pratt, Conversations, p. 278.

39 Rich, "The Baldwin Stamp," p. 55.

40 Ibid.

41 Ibid.

42 Ibid.

43 Toni Morrison, “The Fisherwoman," foreword to Robert Bergman's A Kind of Rapture (New York, Pantheon, 1998), www.nga.gov/audio-video/audio/berg-morrison.html (accessed 21 June 2018).

44 James Baldwin, “Architectural Digest Visits: James Baldwin,” Architectural Digest, August 1987, p. 125.

45 Zaborowska, James Baldwin's Turkish Decade, p. 41.

46 See Ed Pavlić, Who Can Afford to Improvise? James Baldwin and Black Music, the Lyric, and the Listeners (New York, Fordham University Press, 2015).

47 In addition to Me and My House, see J. Vogel, James Baldwin and the 1980s: Witnessing the Reagan Era (Champaign, IL, University of Illinois Press, 2018), and Lynn Orilla Scott's pioneering James Baldwin's Later Fiction: Witness to the Journey (Lansing, MI, Michigan State University Press, 2002).

48 Interview with Kay Bonetti, 1984. 
49 Temporarily entitled "Archiving James Baldwin's House as a Virtual Writer's Museum," this project will have one version at the University of Michigan and another at the National Museum of African American History and Culture at the Smithsonian. As an open access digital exhibit of images of Chez Baldwin and the objects salvaged from the house, it advocates for studying what Ann M. Hale and Shannon R. Smith call "a heightened awareness of the ways historical documents and digital resources present narratives about themselves." See Ann M. Hale and Shannon R. Smith, “You See, But You Do Not Observe': Hidden Infrastructure and Labour in the Strand Magazine and Its Twenty-First-Century Digital Iterations," Victorian Periodicals Review, 49:4 (2016), pp. 664-93. For more information on the digital project, see Magdalena Zaborowska, "Black Matters of Value," American Quarterly (September 2018).

50 Raoul Peck (dir.), I Am Not Your Negro, Velvet Film, 2016.

\section{Works Cited}

Baldwin, James, “Architectural Digest Visits: James Baldwin,” Architectural Digest, August 1987, pp. 122-5.

The Fire Next Time (1963) (New York, Vintage, 1992).

Giovanni's Room (New York, Vintage, 2013).

Notes of a Native Son (Boston, Beacon Press, 2012).

The Price of the Ticket: Collected Nonfiction, 1948-1985 (New York, St. Martin's

Press, 1985).

Baldwin, James, and Raoul Peck, I Am Not Your Negro (New York, Vintage, 2017).

Balfour, Lawrie, The Evidence of Things Not Said: James Baldwin and the Promise of American Democracy (Ithaca, N.Y., Cornell University Press, 2001).

Baym, Nina, "Melodramas of Beset Manhood: How Theories of American Fiction Exclude

Women Authors," American Quarterly, 33:2 (1981), pp. 123-39.

Brown, Bill, Other Things (Chicago, University of Chicago Press, 2016).

Brown, Stephanie, and Keith Clark, "Melodramas of Beset Black Manhood? Meditations on African American Masculinity as Scholarly Topos and Social Menace: An Introduction," Callaloo, 26:3 (2003), pp. 732-7.

Coates, Ta-Nehisi, Between the World and Me (New York, Random House, 2015).

Coole, Diana H., "Inertia of Matter," in Diana H. Coole and Samantha Frost (eds.), New Materialisms: Ontology, Agency, and Politics (Durham, N.C., Duke University Press, 2010), pp. 92-115.

Dayson, Sion, "Another Country: James Baldwin at Home and Abroad," in A. Scott Henderson and P. L. Thomas (eds.), James Baldwin: Challenging Authors (Rotterdam, Sense Publishers, 2014), pp. 77-89.

Dixon, Melvin, Ride Out the Wilderness: Geography and Identity in Afro-American Literature (Champaign, IL, University of Illinois Press, 1987).

Ellison, Ralph, Shadow and Act (New York, Vintage, 1995).

Field, Douglas, All Those Strangers: The Art and Lives of James Baldwin (Oxford, Oxford University Press, 2015).

Gleason, William, Sites Unseen: Architecture, Race, and American Literature (New York, NYU Press, 2011). 
Grosz, Elizabeth, "Feminism, Materialism, and Freedom," in Diana H. Coole and Samantha Frost (eds.), New Materialisms: Ontology, Agency, and Politics (Durham, N.C., Duke University Press, 2010), pp. 70-91.

Hale, Ann M., and Shannon R. Smith, "You See, But You Do Not Observe': Hidden Infrastructure and Labour in the Strand Magazine and Its Twenty-First-Century Digital Iterations," Victorian Periodicals Review, 49:4 (2016), pp. 664-93.

Liu, Alan, "Where is Cultural Criticism in the Digital Humanities?," in M. K. Gold (ed.), Debates in the Digital Humanities (Minneapolis, MN, University of Minnesota Press, 2012), pp. 490-510.

McPherson, Tara, "Introduction: Media Studies and the Digital Humanities," Cinema Journal, 48:2 (2009), pp. 119-23.

"Post-Archive: Scholarship in the Digital Age," lecture given at Brown University, 2012, https://library.brown.edu/create/digitaltalks/lectures/post-archive-scholarship-inthe-digital-age-by-tara-mcpherson/ (accessed 15 March 2018).

Miller, D. Q., Re-Viewing James Baldwin (Philadelphia, PA, Temple University Press, 2000). Morrison, Toni, "The Fisherwoman," foreword to Robert Bergman, A Kind of Rapture (New York, Pantheon, 1998), www.nga.gov/audio-video/audio/berg-morrison. html (accessed 21 June 2018). 1993).

Playing in the Dark: Whiteness and the Literary Imagination (New York, Vintage,

"The Site of Memory," in William Zinsser (ed.), Inventing the Truth: The Art and Craft of Memoir (New York, Houghton Mifflin, 1995), pp. 92-3.

Morton, Timothy, Hyperobjects: Philosophy and Ecology after the End of the World (Minneapolis, MN, University of Minnesota Press, 2013).

Orilla Scott, Lynn, James Baldwin's Later Fiction: Witness to the Journey (Lansing, MI, Michigan State University Press, 2002).

Pavlić, Ed, Who Can Afford to Improvise? James Baldwin and Black Music, the Lyric, and the Listeners (New York, Fordham University Press, 2015).

Peck, Raoul (dir.), I Am Not Your Negro, Velvet Film, 2016.

Posner, Miriam, "What's Next? The Radical, Unrealized Potential of the Digital Humanities," in Matthew K. Gold and Lauren F. Klein (eds.), Debates in the Digital Humanities 2016 (Minneapolis, MN, University of Minnesota Press, 2016), pp. 32-41.

Rich, Adrienne, "The Baldwin Stamp," in A Human Eye: Essays on Art in Society, 1997-2008 (New York, W. W. Norton, 2010), pp. 55-6.

"Why James Baldwin's Words Haven't Lost Their Fire. Review of The Price of the Ticket: Collected Nonfiction, 1948-1985," LA Times (26 September 2004), http://articles.latimes.com/2004/sep/26/books/bk-rich26 (accessed 1 August 2018).

Rusk, Lauren, The Life Writing of Otherness: Woolf, Baldwin, Kingston, and Winterson (New York, Routledge, 2009).

Standley, Fred, and Louise Pratt (eds.), Conversations with James Baldwin (Jackson, MS, University Press of Mississippi, 1989).

Tate, Claudia, Domestic Allegories of Political Desire: The Black Heroine's Text at the Turn of the Century (Oxford, Oxford University Press, 1993).

Vogel, Joseph, James Baldwin and the 1980s: Witnessing the Reagan Era (Champaign, IL, University of Illinois Press, forthcoming 2018).

White, E. F., "The Evidence of Things Not Seen: The Alchemy of Race and Sexuality, in L. King and L. Scott (eds.), James Baldwin and Toni Morrison: Comparative Critical and Theoretical Essays (New York, Palgrave, 2006), pp. 239-60. 
Zaborowska, Magdalena, "Black Matters of Value," American Quarterly (forthcoming, 2018). "From Baldwin's Paris to Benjamin's," in Gevork Hartoonian (ed.), Walter Benjamin and Architecture (New York, Routledge, 2009), pp. 51-74.

James Baldwin's Turkish Decade: Erotics of Exile (Durham, N.C., Duke University Press, 2009).

Me and My House: James Baldwin's Last Decade in France (Durham, N.C., Duke University Press, 2018).

Other Americans, Other Americas: The Politics and Poetics of Multiculturalism (Aarhus, Aarhus University Press, 1998).

\section{Contributor's Biography}

Magdalena J. Zaborowska is Professor in the departments of American Culture and Afroamerican and African Studies, and 2017-18 John Rich Humanities Faculty Fellow at the Institute for the Humanities, University of Michigan, Ann Arbor. She is the author of the MLA award-winning James Baldwin's Turkish Decade: Erotics of Exile (Duke University Press, 2009), and How We Found America: Reading Gender through East European Immigrant Narratives (University of North Carolina Press, 1995) along with numerous articles and essays. Her most recent book, Me and My House: James Baldwin's Last Decade in France, was published by Duke University Press in 2018. 